\title{
USE OF LARGE-SCALE, MULTI-SPECIES SURVEYS TO MONITOR GYRFALCON AND PTARMIGAN POPULATIONS
}

\author{
Jonathan Bart ${ }^{1}$, Mark Fuller $^{2}$, Paul Smith $^{3}$, and Leah Dunn ${ }^{4}$ \\ ${ }^{1}$ US Geological Survey, Forest and Rangeland Ecosystem Science Center, 970 Lusk Street, \\ Boise, ID 83706,USA.E-mail: jon_bart@usgs.gov \\ ${ }^{2}$ US Geological Survey, Forest and Rangeland Ecosystem Science Center, and Boise State \\ University - Raptor Research Center, 970 Lusk Street, Boise, ID 83706, USA \\ ${ }^{3}$ Paul Smith Consulting, $772-7^{\text {th }}$ Conc. South, RR\# 1, Pakenham, \\ Ontario KOA 2XO, Canada
}

${ }^{4}$ Great Basin Bird Observatory, 1755 E. Plumb Lane \#256, Reno, NV 89502, USA

\begin{abstract}
We evaluated the ability of three large-scale, multi-species surveys in the Arctic to provide information on abundance and habitat relationships of Gyrfalcons (Falco rusticolus) and ptarmigan. The Program for Regional and International Shorebird Monitoring (PRISM) has surveyed birds widely across the arctic regions of Canada and Alaska since 2001. The Arctic Coastal Plain survey has collected abundance information on the North Slope of Alaska using fixed-wing aircraft since 1992. The Northwest Territories-Nunavut Bird Checklist has collected presenceabsence information from little-known locations in northern Canada since 1995. All three surveys provide extensive information on Willow Ptarmigan (Lagopus lagopus) and Rock Ptarmigan ( $L$. muta). For example, they show that ptarmigan are most abundant in western Alaska, next most abundant in northern Alaska and northwest Canada, and least abundant in the Canadian Archipelago. PRISM surveys were less successful in detecting Gyrfalcons, and the Arctic Coastal Plain Survey is largely outside the Gyrfalcon's breeding range. The Checklist Survey, however, reflects the expansive Gyrfalcon range in Canada. We suggest that collaboration by Gyrfalcon and ptarmigan biologists with the organizers of large scale surveys like the ones we investigated provides an opportunity for obtaining useful information on these species and their environment across large areas. Received 11 September 2011, accepted 11 October 2011.
\end{abstract}

Bart, J., M. Fuller, P. Smith, AND L. Dunn. 2011. Use of large-scale, multi-species surveys to monitor Gyrfalcon and ptarmigan populations. Pages 263-272 in R. T. Watson, T. J. Cade, M. Fuller, G. Hunt, and E. Potapov (Eds.). Gyrfalcons and Ptarmigan in a Changing World, Volume I. The Peregrine Fund, Boise, Idaho, USA. http://dx.doi.org/10.4080/gpcw.2011.0126

Key words: Surveys, Canada, Alaska, Arctic, Lagopus lagopus, L. muta, Falco rusticolus. 
AS THE PAPERS in this volume show, excellent local studies have been made of Gyrfalcons (Falco rusticolus) and ptarmigan (Lagopus spp.) for decades. But in contrast to many species, few statistically rigorous surveys, covering large portions of the range, have been made for either Gyrfalcons or ptarmigan. Such large scale programs, often termed "status monitoring," identify populations at risk and causes of decline, help formulate management actions and evaluate their success, and document recovery (Spellerberg 2005, Wiens 2009). Status monitoring has been critical in numerous high-profile wildlife issues such as the identification of pesticides as a serious threat to wildlife (Carson 1962), the recovery of many species from pesticide impacts (Sheail 1985), declines of species such as Spotted Owls (Strix occidentalis, Gutiérrez et al. (1995) and Sage Grouse (Centrocercus urophasianus, Schroeder et al. 1999), and the recovery of species under management such as the Peregrine Falcon (Falco peregrinus, White et al. 2002), Kirtland's Warbler (Dendroica kirtlandii, Mayfield 1992), and many waterfowl (Williams et al. 2002). It is difficult, in fact, to think of a major, successful wildlife project in which status monitoring has not played a key role (Bart et al. 2004).

In this paper, we investigate how three multispecies, large-scale surveys might be used to help monitor Gyrfalcon and ptarmigan populations. Specifically, we evaluate how well the surveys permit estimation of distribution and abundance of these birds across large portions of their ranges in North America. We also discuss whether modest and feasible changes in the survey methods might improve the information provided about Gyrfalcons and ptarmigan.

\section{MeTHODS}

Arctic PRISM.-The Program for Regional and International Shorebird Monitoring (PRISM) was established in the late 1990s by Canada and the United States (US) to address a general lack of shorebird monitoring data (Skagan et al. 2003). Since then, participants in Arctic PRISM have developed and conducted surveys widely across the Canadian and Alaskan Arctic (Figure 1). The results of efforts to date in the Arctic are available in a monograph (Bart and Johnston in press), and the detailed data are posted on the internet. Although the Arctic PRISM surveys were designed primarily for shorebirds, surveyors record all species encountered. The primary survey method in Arctic PRISM is double sampling, in which a large sample of plots is searched on foot a single time and a small subset of plots is also searched multiple times to determine actual numbers present. Plots are mainly $0.12-0.16 \mathrm{~km}^{2}$. Rapid surveys last $1-2$ hours and are made by 1-2 people. Plots are selected using stratified random sampling. Strata are delineated using region and habitat (good, fair, or poor for shorebirds). Areas in which nesting birds do not occur (e.g., open water, silt barrens) are excluded. Unusual birds, including falcons, detected only outside the plots, are included as "incidental sightings" and are used in some of the analyses below. In most study areas, intensive surveys were made only for shorebirds and thus did not generate detection ratios for ptarmigan. An intensive study (Bart, unpubl. data) was conducted on the Colville River delta during the mid-1990s and suggested that detection rates for ptarmigan were high while males were defending territories and low after males molted. Most Arctic PRISM surveys were made before males molted so we assume detection rates were high.

During some of the Arctic PRISM surveys in Canada, helicopter surveys were conducted while surveyors were being transported between plots. The helicopter flew 15-30 m above ground at $80-90 \mathrm{~km} / \mathrm{h}$. Two observers recorded birds in a 200- or 400-m strip, centered on the helicopter. Results were summarized as birds per $\mathrm{km}^{2}$ in $25-\mathrm{km}$ segments of the survey route. 


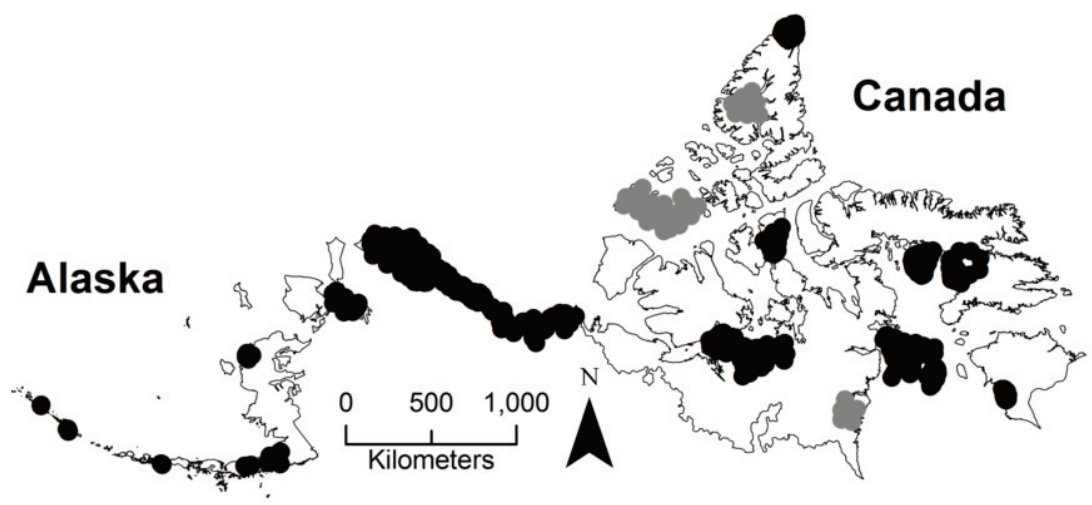

Figure 1. Arctic PRISM survey areas (black) and reconnaissance studies (gray). Each dot is a plot or cluster of 2-4 plots.
As part of Arctic PRISM, preliminary surveys were made in unfamiliar areas to identify good, fair, and poor habitat; collect ground control points so that land cover maps could be prepared; and choose locations for camps in areas where intensive surveys would be undertaken. This reconnaissance work included ground surveys and aerial surveys where plots were often not randomly selected, ground surveys were frequently very brief, and intensivesurvey camps were not established. The results thus provided only a general indication of distribution and abundance.

Alaska Arctic Coastal Plain Aerial Surveys.In 1992, two aerial surveys were established on the coastal plain of Alaska by the US Fish and Wildlife Service. The Arctic Coastal Plain Survey was designed to survey waterfowl, but other species were also recorded (Mallek et al. 2004). Transects covering most of the coastal plain were established at intervals of $\sim 20 \mathrm{~km}$. A fixed-wing airplane flew $38 \mathrm{~m}$ above ground at $176 \mathrm{~km} / \mathrm{h}$. Two observers recorded birds in a $400 \mathrm{~m}$ strip centered on the plane. The North Slope Eider Survey was designed specifically for eiders (Somateria spp., Polysticta stelleri, Larned et al. 2005). It was flown early in the breeding season, when male eiders were still present, and used methods similar to the Arctic Coastal Plain Survey. In 2007, the two surveys were combined and the study area was re-stratified.
Checklist Surveys in Canada.-The Checklist Survey for the Northwest Territories and Nunavut is a volunteer survey begun in 1995 by the Canadian Wildlife Service. It collects information from little-known locations in the Arctic. The protocol is flexible, relying on variable numbers of observers spending variable times at sites of their choosing. Species, and in some cases numbers of individuals, are reported. Individual sites may be visited several times in the same year. Observations presented here were collected during 1965-2009 (although the program started in 1995, it now includes historical data collected much earlier than that date).

\section{RESUlTS}

All three programs collected impressive amounts of information. The PRISM surveys included 1,543 plots each surveyed one time using the rapid method, 88 plots each surveyed multiple times using the intensive method, more than $5,680 \mathrm{~km}$ of aerial surveys, and $>200$ plots surveyed during reconnaissance studies (Figure 1). The Arctic Coastal Plain aerial surveys included $61,645 \mathrm{~km}$ of transects covering nearly all parts of the coastal plain on the North Slope of Alaska. The checklist program includes more than 125,000 records on 12,600 checklists from 6,800 unique locations in the Arctic. 
Table 1. Densities (birds $/ \mathrm{km}^{2}$ ) of ptarmigan as estimated by the Arctic PRISM surveys (see Figure 1 for survey locations).

\begin{tabular}{|c|c|c|c|c|c|c|c|}
\hline \multirow[b]{2}{*}{ Region } & \multirow[b]{2}{*}{$\mathrm{N}$ plots } & \multicolumn{2}{|c|}{ Willow Ptarmigan } & \multicolumn{2}{|c|}{ Rock Ptarmigan } & \multicolumn{2}{|c|}{ Both species } \\
\hline & & Density & SE & Density & SE & Density & SE \\
\hline Aleutian Islands & 60 & 0.00 & 0.00 & 5.57 & 2.60 & 5.57 & 2.60 \\
\hline Western Alaska & 129 & 28.47 & 12.58 & 0.86 & 1.37 & 29.33 & 25.31 \\
\hline Northern Alaska & 636 & 7.45 & 1.64 & 1.28 & 0.51 & 8.73 & 3.43 \\
\hline Mainland Canada - west ${ }^{1}$ & 171 & 9.00 & 3.38 & 2.89 & 2.02 & 11.89 & 7.87 \\
\hline Mainland Canada - east² & 218 & 1.39 & 1.27 & 2.65 & 1.47 & 4.04 & 3.88 \\
\hline Canadian Archipelago & 502 & 0.30 & 0.50 & 0.11 & 0.14 & 0.40 & 1.03 \\
\hline
\end{tabular}

${ }^{1}$ Yukon Territory to Mackenzie Delta

2 Kent Peninsula to Quebec

Table 2. Density (birds $/ \mathrm{km}^{2}$ ) of Willow and Rock Ptarmigan in relation to habitat type.

\begin{tabular}{|c|c|c|c|c|c|c|}
\hline \multirow[b]{2}{*}{ Species } & \multicolumn{2}{|c|}{ Wetlands } & \multicolumn{2}{|c|}{ Moist areas } & \multicolumn{2}{|c|}{ Dry areas } \\
\hline & Density & SE & Density & SE & Density & SE \\
\hline Willow Ptarmigan & 2.64 & 0.69 & 5.77 & 1.05 & 8.27 & 2.39 \\
\hline Rock Ptarmigan & 0.49 & 0.12 & 1.71 & 0.40 & 1.32 & 0.40 \\
\hline Both & 3.13 & 0.69 & 7.48 & 0.95 & 9.58 & 2.34 \\
\hline
\end{tabular}

On PRISM surveys, estimates of ptarmigan density were highest in western Alaska (30 birds $/ \mathrm{km}^{2}$ ), declined from west to east in northern Alaska and mainland Canada, and were lowest $\left(0.40\right.$ birds $\left./ \mathrm{km}^{2}\right)$ in the Canadian archipelago (Table 1). Rock Ptarmigan (Lagopus muta) were more common farther north. For example, in the Canadian Archipelago, Willow Ptarmigan (L. lagopus) were recorded only on Southampton and Prince Charles Islands, whereas Rock Ptarmigan were recorded only on Melville, Prince Patrick, and Ellesmere Islands. Rock Ptarmigan reached their highest abundance on the Aleutian Islands and were uncommon on the Yukon Delta study area, whereas the reverse was true for Willow Ptarmigan. The PRISM ground surveys also revealed that density of ptarmigan was highest in uplands and lowest in wetlands (Table 2). This pattern was evident for both species, except that Rock Ptarmigan were recorded slightly (but not significantly) more often in moist habitats. Despite covering a large area of the Gyrfalcon's range, the standard PRISM ground surveys recorded only four individuals, all in Alaska (two on the Alaska Peninsula and two on the North Slope). The PRISM reconnaissance surveys recorded five Gyrfalcons on Melville and Ellesmere Islands, all on aerial surveys.

The aerial surveys in northern Alaska provided a detailed picture of ptarmigan distribution (Figure 2). Ptarmigan were most common in the south-central portion of the coastal plain, especially within the National Petroleum Reserve-Alaska. They were much less common in the Arctic National Wildlife Refuge and close to the coast. The surveyors recorded only "falcons," not distinguishing Peregrines and Gyrfalcons. They recorded 29 falcons in 28 separate sightings, a rate of one falcon sighting per 2,200 km of survey transect. On the PRISM surveys, 2 of 11 falcon sightings were Gyrfalcons, suggesting that Gyrfalcon 


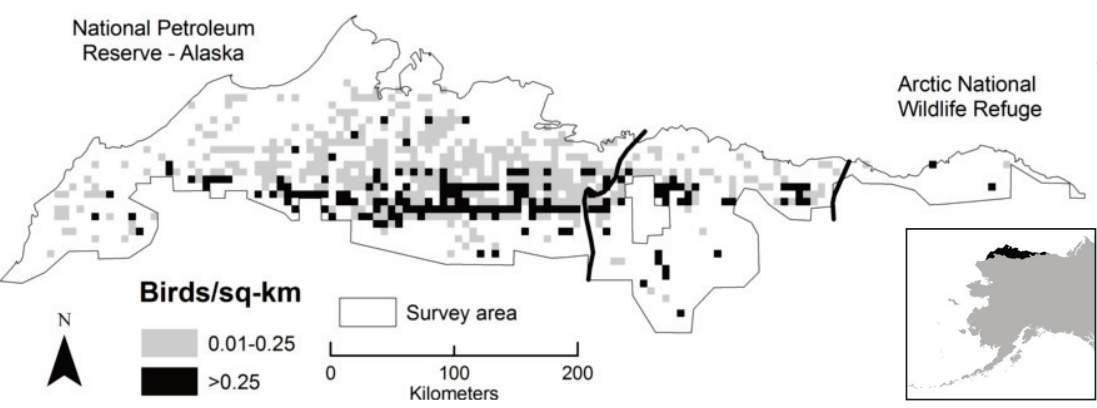

Figure 2. Density of ptarmigan recorded on aerial surveys of the North Slope of Alaska, 1992-2010.

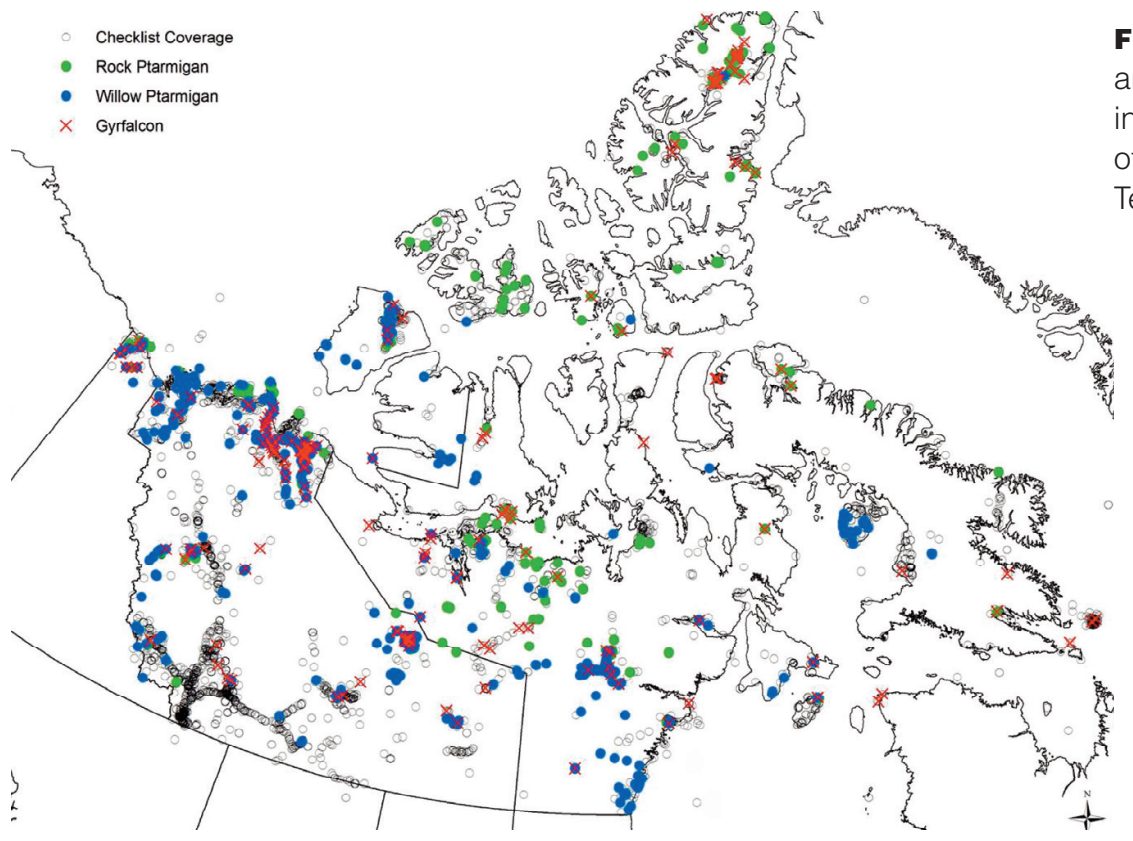

Figure 3. Ptarmigan and Gyrfalcon records in the Checklist Survey of the Northwest Territories and Nunavut.

sightings on the aerial surveys were probably very rare.

The checklist data showed that ptarmigan are widely distributed through northern Canada, with Willow Ptarmigan occurring principally on the mainland and Rock Ptarmigan occurring mainly on the islands (Figure 3). The survey recorded dozens of Gyrfalcons and appears to effectively delineate their range in Canada.

\section{Discussion}

Hannon et al. (1998) and Holder and Montgomery (1993) reviewed the densities of Willow and Rock Ptarmigan respectively. In both studies, the authors commented that density varies widely among populations of both species. For example, Hannon et al. (1998) reported $\sim 2$ Willow Ptarmigan per $\mathrm{km}^{2}$ in Newfoundland and up to 150 per $\mathrm{km}^{2}$ in 
British Columbia. Holder and Montgomery (1993) reported densities for Rock Ptarmigan in Canada, Iceland, and Scotland and concluded that in North America average density is probably $1-4$ birds $/ \mathrm{km}^{2}$ which is consistent with the PRISM surveys. PRISM results suggest that these reports are part of a broad pattern in abundance, with highest densities in the west, especially south of the Brooks Range, and lowest in northern and eastern Canada. Our results for habitat affinities are consistent with the descriptions in Hannon et al. (1998) and Holder and Montgomery (1993).

It is noteworthy that ptarmigan density was much higher on the coastal plain of Alaska, including in areas only a few dozen $\mathrm{km}$ from known breeding sites of Gyrfalcons (Clum and Cade 1994), yet the falcon was hardly ever recorded in this area. The most likely explanation is lack of suitable nest sites as reported by Morozov (2011) on Kolguey Island, Russia. Another striking finding from the surveys is that while Gyrfalcons occur widely across the Canadian archipelago, they are not common there, as suggested by our finding only a few birds in all of the PRISM ground and aerial surveys. Taken together, the findings from northern Alaska and northern Canada suggest that if more southerly regions become unsuitable due to global warming, Gyrfalcons may have little ability to shift their range northward. A warming trend will not create suitable nest sites in the coastal plain of Alaska, and densities are presumably low in the Canadian archipelago because productivity in general is low (Marsh 1988). It will probably take many centuries for the thick layers of peat, which support high densities of flora and fauna in more southerly tundra regions, to accumulate. Thus, these areas are not likely to become more suitable for Gyrfalcons just because the more southerly areas become less suitable. In Alaska, perhaps Gyrfalcons will nest on human-made structures associated with oil exploration, such as Ritchie (1991) and Morozov (2011) suggested might happen on Kolguey Island, or perhaps artificial nest sites can be established as Østlyngen and Johansen (2011) did in Norway. Management agencies thus may be facing the possibility that Gyrfalcons may become another "conservation reliant" species (Scott et al. 2010), so both Gyrfalcons and ptarmigan are good candidates for a status monitoring program. At least 16 papers in this symposium discuss the current and/or past population status of Gyrfalcons and ptarmigan around the world, at least 15 papers discuss threats, and at least four papers discuss ways to improve monitoring programs. Thus, an excellent foundation exists for working with large-scale programs so that they provide the most information possible on the status of Gyrfalcons and ptarmigan.

Opportunities may exist to work with the organizers of large-scale monitoring programs like the ones we investigated, to improve the information they provide about Gyrfalcons and their prey. Arctic PRISM employs a sophisticated stratification system based on both region and habitat. One of the strengths of this approach is that the stratification can be adapted to local needs as was done, for example, in the Mackenzie Delta in response to concerns about the effects of oil development on birds (Rausch and Johnston in press). Stratification in the PRISM surveys has not yet focused on cliff-nesting raptors, probably because raptor biologists have not been deeply involved with the designers of PRISM, yet this might be accomplished (e.g., Ritchie et al. 2003, Booms et al. 2010, Fuller et al. 2011, Mossop 2011) for future PRISM surveys. Pilots and observers conducting aerial surveys must focus on the priority species (usually waterfowl), yet if reasons existed to distinguish falcons, it is possible that those workers would do so. In studying the ptarmigan data, we noticed that most of the sightings occurred in only a few years, suggesting that observers may not have focused consistently on these species. On the Arctic Coastal Plain Survey, $<40$ ptarmigan were recorded in all years except 2001, when 323 were recorded. On the North Slope Eider Survey, ptarmigan were 
recorded only during 1992-1997, and $82 \%$ of the records were from 1995 and 1996, which may reflect either a change in effort to record ptarmigan, or a change in their abundance. As noted above, these surveys were designed for waterfowl in general and eiders specifically, whereas ptarmigan were not a focal species. But if reasons existed to strive for more consistency in recording ptarmigan, doing so might be possible. The Checklist Survey provided most of the information about Gyrfalcons, and its methods are currently being improved; raptor biologists might be able suggest ways that the program could more effectively gather information on Gyrfalcons.

More information is readily available on all of these surveys. The PRISM project results (Bart and Johnston in press) provide data for dozens of arctic species that occurred in or near the survey plots, including nearly 1,000 estimates of density and population size for 19 species of shorebirds, all with standard measures of precision. Details will be available from the Coordinated Bird Monitoring Database (http://iwcbm.dev4.fsr.com/IWCBM/) as soon as the Studies in Avian Biology volume has been published (Bart and Johnston in press). Information on the aerial surveys in northern Alaska, and for many other aerial surveys, is available from the US Fish and Wildlife Service in Alaska, http://www.arlis.org. The Checklist Survey of the Canadian Wildlife Service, at http://www.ec.gc.ca/reom-mbs/default.asp? lang=En\&n=60E48D07-1, provides details and data for many more species. Other sources of large scale information include eBird and the Avian Knowledge Network (Sullivan et al. 2009). We suspect that those interested in Gyrfalcons and ptarmigan might benefit by using these sources of information and collaborating with the leaders of these programs to make them even more useful in studying and conserving these species.

\section{ACKNOWLEDGMENTS}

We appreciate the several reviewers' comments. Any use of trade, product, or firm names is for descriptive purposes only and does not imply endorsement by the US Government.

\section{Literature Cited}

Bart, J., K. P. Burnham, E. H. Dunn, C. M. FRANCIS, AND C. J. RALPH. 2004. Goals and strategies for estimating trends in landbird abundance. Journal of Wildlife Management 68:611-626.

BART, J. AND V. JOHNSTON. Arctic shorebirds in North America: Results of a ten-year monitoring program. Studies in Avian Biology: in press.

BOOMS, T. L., P. F. SCHEMPF, B. J. MCCAFFERY, M. S. LiNDBERG, AND M. R. FULLER. 2010. Detection probability of cliff-nesting raptors during helicopter and fixed-wing aircraft surveys in western Alaska. Journal of Raptor Research 44: 175-187.

CARson, R. C. 1962. Silent Spring. Houghton Mifflin, New York, New York, USA.

Clum, N. J., AND T. J. CADE. 1994. Gyrfalcon (Falco rusticolus). In A. Poole and F. Gill (Eds.). The Birds of North America, no. 114. Academy of Natural Sciences, Philadelphia, and American Ornithologists' Union, Washington, DC, USA.

Fuller, M. R., P. F. SChempF, AND T. L. Booms. 2011. Developing Gyrfalcon surveys and monitoring for Alaska. In $\mathrm{R}$. T. Watson, T. J. Cade, M. Fuller, G. Hunt, and E. Potapov (Eds.). Gyrfalcons and Ptarmigan in a Changing World. The Peregrine Fund, Boise, Idaho, USA. http://dx. doi.org/10.4080/gpcw.2011.0129

Gutiérrez, R. J., A. B. Franklin, and W. S. LAHAYE. 1995. Spotted Owl (Strix occidentalis). In A. Poole and F. Gill (Eds.). The Birds of North America, no. 179. Academy of Natural Sciences, Philadelphia, and American Ornithologists' Union, Washington, DC, USA. 
Hannon, S. J., P. K. EAson, And K. Martin. 1998. Willow Ptarmigan (Lagopus lagopus). In A. Poole and F. Gill (Eds.) The Birds of North America, no. 369. Academy of Natural Sciences, Philadelphia, and American Ornithologists' Union, Washington, DC, USA.

Holder, K., AND R. MONTGOMERY. 1993. Rock Ptarmigan (Lagopus mutus). In A. Poole and F. Gill (Eds.). The Birds of North America, no. 114. Academy of Natural Sciences, Philadelphia, and American Ornithologists' Union, Washington, DC, USA.

Larned, W., R. Stehn, and R. Platte. 2005. Eider breeding population survey, Arctic Coastal Plain, Alaska. US Fish and Wildlife Service, Division of Migratory Bird Management. Soldotna, Alaska, USA. http://www. arlis.org

Mallek, E. J., R. Platte, and R. Stehn. 2004. Aerial breeding pair surveys of the Arctic Coastal Plain of Alaska-2004. US Fish and Wildlife Service, Waterfowl Management. Fairbanks, Alaska, USA. <http:// www.arlis.org>

Marsh, J. H. 1988. Arctic Archipelago. The Canadian Encyclopedia. Hurtig Publishers, Toronto, Canada.

MAYFIELD, H. 1992. Kirtland's Warbler (Dendroica kirtlandii). In A. Poole and F. Gill (Eds.). The Birds of North America, no. 19. Academy of Natural Sciences, Philadelphia, and American Ornithologists' Union, Washington, DC, USA.

Morozov, V. V. 2011. Ecological basis for the distribution and breeding of Gyrfalcons in the tundra of European Russia and preconditions for spreading to new grounds. In $\mathrm{R}$. T. Watson, T. J. Cade, M. Fuller, G. Hunt, and E. Potapov (Eds.). Gyrfalcons and Ptarmigan in a Changing World. The Peregrine Fund, Boise, Idaho, USA. http://dx. doi.org/10.4080/gpcw.2011.0222

Mossop, D. H. 2011. Long-term studies of Willow Ptarmigan and Gyrfalcon in the Yukon Territory: A collapsing 10-year cycle and its apparent effect on the top predator.
In R. T. Watson, T. J. Cade, M. Fuller, G. Hunt, and E. Potapov (Eds.). Gyrfalcons and Ptarmigan in a Changing World. The Peregrine Fund, Boise, Idaho, USA. http:// dx.doi.org/10.4080/gpcw.2011.0206

Østlyngen, A., K. Johansen, and P. A. HALVORSEN. 2011. Artificial nests-a remedial action in maintaining viable Gyrfalcon populations? In R. T. Watson, T. J. Cade, M. Fuller, G. Hunt, and E. Potapov (Eds.). Gyrfalcons and Ptarmigan in a Changing World. The Peregrine Fund, Boise, Idaho, USA. http://dx.doi.org/10. 4080/gpcw.2011.0314

Rausch, J., AND V. Johnston. Yukon North Slope and Mackenzie Delta. In J. Bart and V. Johnston (Eds.). Arctic Shorebirds in North America: Results of a Ten-Year Monitoring Program, Chapter 5. Studies in Avian Biology: in press.

Ritchie, R. J. 1991. Effects of oil development on providing nesting opportunities for Gyrfalcons and Rough-legged Hawks in northern Alaska. Condor 93:180-184.

Ritchie, R. J., A. M. Wildman, And D. A. YOKEL. 2003. Aerial surveys of cliff-nesting raptors in the National Petroleum Reserve-Alaska, 1999, with comparisons to 1977 . Technical note 413. US Department of the Interior, Bureau of Land Management, Fairbanks, Alaska, USA.

Schroeder, M. A., J. R. Young, And C. E. BRAUn. 1999. Sage grouse (Centrocercus urophasianus). In A. Poole and F. Gill (Eds.). Birds of North America, no. 25. Academy of Natural Sciences, Philadelphia, and American Ornithologists' Union, Washington, DC, USA.

Scott, M. J., D. D. Goble, A. M. Haines, J. A. Wiens, AND M. C. NeEl. Conservationreliant species and the future of conservation. Conservation Letters 3:91-97.

ShEAIL, J. 1985. Pesticides and Nature Conservation. Clarendon Press, Oxford, UK.

Skagen, S., J. BArt, B. Andres, S. Brown, G. DONALDSON, B. HARRINGTON, V. JOHNSTON, S. L. JoNeS, AND R. I. G. MORRISON. 2003. Monitoring the shorebirds of North Amer- 
ica: Towards a unified approach. Wader Study Group Bulletin 100:102-104.

SPELlERBERG, I. F. 2005. Monitoring ecological Change, $2^{\text {nd }}$ ed. Cambridge University Press, Cambridge, UK.

Sullivan, B. L., C. L. Wood, M. J. IlifF, R. E. Bonney, D. Fink, AND S. Kelling. 2009. eBird: A citizen-based bird observation network in the biological sciences. Biological Conservation 142:2282-2292.

White, C. M., N. J. Clum, T. J. Cade, and W. G. Hunt. 2002. Peregrine Falcon (Falco peregrinus). In A. Poole and F. Gill (Eds.). The Birds of North America, no. 660. Academy of Natural Sciences, Philadelphia, and American Ornithologists' Union, Washington, DC, USA.

WIENS, J. A. 2009. Is 'monitoring' a dirty word? Bulletin of the British Ecological Society 40:39-40.

Williams, B. K., J. D. Nicols, AND M. J. ConROY. 2002. Analysis and Management of Animal Populations. Academic Press, New York, New York, USA. 
- Bart et Al. - 